\title{
A SUPERAÇÃo INTUITIVA DA METAFÍSICA: O KANTISMO DE BERGSON ${ }^{1}$
}

\author{
Camille Riquier ${ }^{2}$ \\ Tradução de Débora Cristina Morato Pinto ${ }^{3}$
}

\begin{abstract}
Resumo: O texto aqui apresentado analisa aspectos relevantes da complexa relação que Bergson estabelece com Kant. Defende-se a hipótese de que Bergson não pode ser considerado mero adversário do filósofo alemão, mas seu projeto filosófico tem como objetivo retomar a metafísica, levando em consideração os limites que a crítica kantiana lhe impôs. Nesse sentido, a Crítica da Razão Pura, à qual Bergson dedicou sua atenção, serve de guia e apoio para a colocação das questốes propriamente metafísicas, as quais a filosofia da duração busca responder. Procuramos mostrar também que, se Bergson criticou Kant em vários momentos da sua obra, foi apenas na medida em que a Crítica o impedia e impedia os outros de avançar. A relação entre as interdiçôes kantianas para a razão especulativa e as ilusōes da inteligência dissolvidas em $A$ Evolução Criadora revela como Kant condensa ilusôes que existiam antes dele e que, nesse sentido, Bergson não é nem pré-crítico, nem pós-kantiano. Em suma, defendemos que Bergson desloca as análises críticas e rompe com Kant do interior de sua filosofia, que ele divide em duas tendências - uma que ele rejeita, como antiga, outra da qual ele se apropria.
\end{abstract}

Palavras-Chave: Bergson; Metafísica; Kant; Crítica; Duração; Intuição.

1 "La relève intuitive de la métaphysique: le kantisme de Bergson." Texto originalmente publicado em RIQUIER, C.; WORMS, F. Lire Bergson. Paris: PUF, 2011, p. 35-59. Tradução de Débora Morato Pinto. Nota da tradutora sobre o título: o termo "superação" foi escolhido para a tradução de "relève", substantivo cujo significado mais direto é "substituição" ou "revezamento", mas, derivado do verbo "relever", que possui entre os seus significados "reconstruir", "reerguer", "retomar", "remontar", "sublinhar", "substituir", "revezar". A dificuldade em traduzi-lo envolve ainda o sentido preciso que o autor do artigo intencionou, e que se refere à noção hegeliana de Aufhebung, por sua vez, referida ao verbo aufheben. O título remete, portanto, diretamente a Hegel e à ideia de um movimento imanente do pensamento, pelo qual se ultrapassa um "anterior", suprimindo-o, ao mesmo tempo em que o conserva, realizando virtualidades nele contidas, talvez sob um outro ponto de vista. Riquier cita explicitamente o verbo aufheben e seu duplo sentido: "ultrapassar" e "realizar". Poderíamos traduzir "relève" por "retomada" ou "reconstrução", mas as consideraçôes aqui apresentadas nos encaminharam para "superação" como opção mais adequada. A tese central do artigo confirma a adequação dessa escolha, pois se trata de defender que Bergson supera a Crítica da Razäo Pura e retoma a metafísica, no ponto em que o filósofo alemâo a abandonou, mas levando em consideração os limites que a crítica kantiana lhe impôs e através de um processo de conhecimento presidido pela intuição da duração. Sobre o sentido hegeliano, ver PERTILLE, J. Aufhebung, meta-categoria da lógica hegeliana. Revista Eletrônica Estudos Hegelianos, Ano 8, n. 15, p. 58-66, dez. 2011.

http://dx.doi.org/10.1590/S0101-317320170002000012

${ }^{2}$ Camille Riquier, Agregée et Doutor em Filosofia pela Université Paris IV, é Maître de Conférences na Faculté de Philosophie do Institut Catholique de Paris. Autor de diversos artigos e capítulos de livros no campo da filosofia francesa contemporânea, escreveu notadamente a obra Archéologie de Bergson. Temps et Métaphysique. Paris: PUF, 2009 ("Epimethée”).

3 Professora Associada do Departamento de Filosofia da Universidade Federal de São Carlos. Orientadora credenciada no Programa de Pós-Graduação em Filosofia, na mesma instituição. Pesquisadora do CNPq desde 2006. E-mail: deboramorato@uol.com.br 
Ao conservar o nome de metafísica, ao restaurar suas prerrogativas, seria Bergson um filósofo pré-crítico desviado de nossa modernidade? Teria ele avançado imprudentemente ali onde o tribunal kantiano deixa regularmente cair seu cutelo, quando ele declara possível o que a Crítica da Razão Pura afirma ser nada menos que impossível? Ou bem é ele um filósofo resolutamente moderno, o qual tomou sempre o cuidado de suprimir as objeçôes que Kant lhe podia infligir, senão as ilusôes sobre as quais sua Crítica repousava? A questão deve ser elaborada de outra maneira, na impossibilidade de poder ser definida nitidamente, ao mesmo tempo em que deve ser elucidada a complexa relação que Bergson estabelece com Kant. Se ele passou seus estudos ao lado de toda influência alemã, se começou mesmo a escrever sem se preocupar com as interdiçôes kantianas que pesavam sobre sua empresa, o obstáculo colocado por Kant sobre seu caminho acabou por impor-se, uma vez que lhe era lembrado incessantemente. Ainda que já estivesse andando, asseguravam-lhe que patinava no lugar, se é que ignorar a virada crítica náo devesse tomar o lugar de uma objeção aniquiladora contra sua metafísica. O fato é que essa "ruptura" com o kantismo, a qual o Ensaio tinha apenas feito "entrever" (BERGSON, 2009, p. 21), se acentuou cada vez mais. Com Matéria e Memória, discretamente, depois em sua "Introdução à Metafísica", abertamente, Bergson quis superar o obstáculo, confrontar-se com ele, pois ali estava a atmosfera de seu tempo, lá estava também a linguagem que lhe era necessário tomar emprestada, se quisesse ser compreendido: "Introdução à Metafísica" (1903), como lembra Bergson, "[...] foi escrita numa época em que o criticismo de Kant e o dogmatismo de seus sucessores eram geralmente admitidos, senáo como conclusão, ao menos como ponto de partida da especulação filosófica." (BERGSON, 2009, p. 176, nota 1)4. E, uma vez que então se proclamava o fim da metafísica ("conclusão"), Bergson devia nela nos reintroduzir, depois que Kant havia feito sua crítica ("ponto de partida”).

É preciso, entretanto, entrar num acordo. A metafísica, todavia, tinha sido detida? Rigorosamente falando, ela é ou ela não é - e o paradoxal seria que Bergson tivesse tido que esperar o confronto com Kant para começar a fazer metafísica. Teria sido necessário esperar que $A$ Evolução Criadora dissipasse as ilusôes do nada e da desordem das quais a inteligência se cerca, e que a persuadem sobre um real longínquo ou inacessível. Mas, a bem da verdade, tais ilusôes já estão dissipadas para uma inteligência que a intuição desde

\footnotetext{
${ }^{4}$ Passagem de "Introduction à la Métaphysique" (1903). Ver também Introdução II a O Pensamento e o movente, (2009, p. 75).
} 
muito tempo "sacudiu de seu sono" (BERGSON, 2009, p. 67) dogmático, como ocorreu a Bergson, desde o seu primeiro livro; elas são mais tarde apenas reconhecidas enquanto tais. $\mathrm{O}$ criticismo, o qual repousa inteiramente sobre tais ilusôes, pode ser por longo tempo ignorado, porque ele não entrava nem atrasa o avanço de um pensamento que já respirou o ar soprado pela coisa mesma, tal qual ela é "em si", mas somente o de um pensamento nublado por ideias que ele mesmo construiu e que carrega consigo "[...] como impedimenta." (BERGSON, 2009, p. 22). É assim que as questôes críticas náo perturbam senão aquele que se as coloca ("que posso saber?", "que devo fazer?", "o que me é permitido esperar?"). O pensamento humano "[...] pode tão bem passar ao lado da filosofia kantiana e das 'teorias do conhecimento' originadas do kantismo" (BERGSON, 2009, p. 69) e ir diretamente às questóes essenciais, quanto a moratória kantiana tinha acabado por fazer com que elas não pudessem mais se colocar para ninguém: "[...] de onde viemos? que somos nós? para onde vamos? Eis as questóes vitais, diante das quais nós nos colocaríamos de imediato se filosofássemos sem passar pelos sistemas". Eis, com efeito, questôes, pascalianas em sua formulação, nas quais Bergson só pode reinvestir depois de tê-las salvado da tormenta dialética em que Kant as havia deixado, sem resposta, para náo dizer abandonadas ao esquecimento, ao suspendê-las à psicologia racional. ${ }^{5}$ Em outros termos, o único meio encontrado por Bergson para responder à questão "o que é o homem?” foi começar por se colocá-la ingenuamente, sem passar, como Kant, pelo estudo prévio do mecanismo de nosso pensamento. "O metafísico não larga assim a filosofia pela crítica, o fim pelos meios, a presa pela sombra" (BERGSON, 2009b, p. 2) e, se Bergson criticou Kant, aqui ou ali, é na medida em que a crítica o impedia e impedia os outros de avançar. A crítica que ele lhe endereça teria podido, aliás, cair com o obstáculo, se Bergson não se tivesse proposto mais amplamente criticar o mecanismo natural de nossa inteligência e suas ilusóes supracitadas, de fato presentes desde Zenão e as quais Kant teve simplesmente o mérito de ter sistematizado. O nada precede o ser e a desordem precede a ordem? "Todo objetivo da Crítica da Razão Pura consiste com efeito em explicar como uma

\footnotetext{
${ }^{5}$ Quem se recorda, com efeito, de que elas são apresentadas na primeira ediçấo de 1781? "Sobre essa aparência transcendental de nossos conceitos psicológicos se fundam ainda três questōes dialéticas, que definem o objetivo específico da psicologia racional e não podem ser resolvidas exceto pelas análises precedentes, a saber, as questốes: 1 . Da possibilidade da união da alma com o corpo orgânico, isto, da animalidade e do estado da alma na vida do ser humano; 2 . Do começo dessa união, isto é, da alma quando do nascimento e antes do nascimento do ser humano; 3. Do final dessa uniáo, isto é, da alma quando da morte e depois da morte do ser humano (questão da imortalidade)." (KANT, I. Critique de la raison pure, AK, IV, 240, A 384, tr. A. Renaut, Paris, 2008, p. 385).
} 
ordem definida vem se acrescentar a materiais supostamente incoerentes." (BERGSON, 2009, p. 69). Kant condensa ilusões que existiam antes dele. Nesse sentido, Bergson não é nem pré-crítico, nem pós-kantiano. E, ainda nesse sentido, ele jamais foi o "adversário de Kant". 6 (i) Pós-kantiano? Se a Crítica é a prova de fogo pela qual Bergson aceitou fazer passar sua metafísica, para que ela ali morra e renasça tal qual uma fênix, esse enfrentamento do perigo não basta para fazer de Bergson um pós-kantiano, em sentido estrito. Parafraseando-o, nós podemos afirmar que Bergson teria sido o mesmo sem Kant, ainda que tivesse "[...] sem dúvida escrito outra coisa." (BERGSON, 2009, p. 124). Kant é para ele o que, a seus olhos, Descartes foi para Espinosa, a saber, a língua que se falava à sua época e com a qual era necessário revestir sua doutrina para comunicá-la. Mais que qualquer outro texto, "Introdução à Metafísica” conserva a sua marca. O fundo intuitivo da doutrina bergsoniana remonta, porém, efetivamente, para além de Kant, ao próprio Descartes: um cogito em ato imerso na duraçáo concreta. (ii) Pré-crítico, então? Bergson o é muito menos e, ainda que cartesiano, ele tomou conhecimento dos obstáculos que poderiam impedir seu caminho, superou-os à medida que os encontrava e, de fato, quis reerguer a metafísica depois que Kant a tinha derrubado. E ele não pôde derrubar tais obstáculos sem atacar as ilusôes que se encontravam em suas raízes, pelas quais Kant compartilhava ainda muito com a metafísica dos Antigos que ele combatia.

Um passo ao lado deve ser dado se quisermos identificar a justa relação entre os dois filósofos, suficientemente sutil para não poder ser encerrada na alternativa de partida, suficientemente franca e, ao final, surpreendente, quando se pensa nas declaraçóes de $A$ Evolução Criadora, onde, no último capítulo, Bergson se considera kantiano, em lugar de manter a oposição massiva que se teria ingenuamente esperado. Depois de Descartes e antes de Spencer, Kant é um outro "precursor perdido" (PANERO, 2008) de Bergson. Assim como Descartes, Kant contém, a seus olhos, duas vias possíveis para a filosofia que refletem as duas tendências dominantes entrelaçadas no elã vital e que prosseguem no homem: a intuição e a inteligência. Bergson desloca, assim, as linhas e rompe com Kant do interior de sua filosofia, que ele divide em dois kantismos: um que ele rejeita, como antigo, outro do qual ele se apropria. Não se trata, porém, de prolongar em Kant um bergsonismo larval, como A. Panero considerou, mas, ao contrário, de restituir o kantismo que se realizou em Bergson, o qual se engajou numa via que o filósofo alemão havia

\footnotetext{
${ }^{6}$ Trata-se do título da obra de M. Barthélémy-Madaule, Bergson adversaire de Kant. Paris: PUF, 1966.
} 
apenas esboçado, sem, entretanto, segui-la, por se ter privado de toda intuição "intelectual". Então, "Introdução à Metafisica" não é somente um acerto de contas com Kant, como se este constituísse uma barreira que detivesse "o impulso da metafísica" (BERGSON, 2009, p. 22) e que seria preciso ver ceder, diante da plenitude do mar. Bergson ali mostra, sobretudo, que a metafísica já iniciada e que ele pretende desenvolver não tem mais nada em comum com aquela que se praticava antes de Kant, que ele é mesmo o primeiro a reerguê-la do golpe que este lhe havia dado, e que ele se propóe modificar suficientemente seu estatuto para que ela possa suportar todas as críticas, para que ela tenha êxito sozinha em superá-las, utilizando surpreendentemente a Crítica para esse fim, como se fosse uma alavanca para ir mais longe. Assim, se acreditarmos em Bergson, uma metafísica intuitiva que se instala na duração pura não está nem aquém, nem além da crítica kantiana, mas pode passar por ela, atravessá-la de corpo inteiro, uma vez que pretende ultrapassá-la, prolongá-la na via que o próprio Kant abriu, a fim de realizar suas virtualidades sufocadas. Sobre vários pontos, com efeito, Bergson seguiu os traços da primeira Crítica, a Crítica da Razão Pura, a única que ele levou em consideração. Não estamos ainda no tempo em que os comentadores procurarão, na terceira Crítica, como conciliar as duas primeiras. Péguy lembrava que, à época, "[...] os kantianos se dividiam naturalmente em dois: aqueles que refletiam sobre a Crítica $d a$ Razão Pura [...] e os que viviam sobre a Crítica da Razão Prática" e que "[...] um abismo os separava” (PÉGUY, 1905, p. 288). Excetuando-se as objeçóes pontuais endereçadas à moral kantiana, no primeiro capítulo das Duas Fontes, Bergson está, antes, entre aqueles que meditaram profundamente sobre a primeira Crítica, e percebe-se que ele respeita as suas divisôes, que sua obra segue os seus passos para reformá-la do interior e nela penetra suficientemente, para ali preparar uma via que possa nos introduzir novamente à metafísica. O kantismo de Bergson acabará seguramente por trair o espírito de Kant, todavia, o que ele pretende superar - aufheben -, no duplo sentido de "ultrapassar" e "realizar", ao se amparar na intuição, é a própria metafísica kantiana, aquela cujas condiçôes de possibilidade ele havia liberado, antes de afirmar a sua impossibilidade. Sem paradoxo, a metafísica bergsoniana deverá ser uma retomada intuitiva da metafísica que Kant havia abandonado aos sonhos vazios da razão pura, na falta de uma experiência sobre a qual pudesse apoiá-la. Ao recusar, por sua vez, a antiga metafísica, a qual é preciso louvar Kant por tê-la arrasado, Bergson pretende relançar pelo viés do kantismo “[...] a metafísica dos modernos" (BERGSON, 2009, p. 224), tal qual ela já tinha obtido sua fonte em Descartes, propondo uma metafísica tão moderna, 
senão mais, que a crítica que Kant havia formulado, a qual acreditava poder substituir a metafísica definitivamente.

\section{A EXPERIÊNCIA INTEGRAL}

As primeiras páginas de "Introdução à Metafísica" são célebres e, entretanto, quantos mal-entendidos elas suscitaram! Tais mal-entendidos originaram-se do fato de que se emprestou a Bergson uma definição de metafísica que ele próprio atribuía a todos e que ele não pôde retomar por sua conta, sem submetê-la à revisão: "[...] os filósofos estão de acordo" (BERGSON, 2009, p.177) em distinguir duas maneiras profundamente diferentes de conhecer - por análise e por intuição. Uma gira em torno da coisa e toma dela uma multiplicidade de vistas; a outra entra na coisa e a conhece absolutamente. Concebe-se que, se Bergson hesitara diante do termo intuição, que “[...] se presta à confusão" (BERGSON, 2009, p. 25), é porque todas as metafísicas o arrogam para si e, ao adotá-lo, ele provocava confusão entre a antiga metafisica, que ele rejeitava, e a nova metafísica por ele proposta. Mas é a mesma razáo que deve tê-lo incitado a empregar o termo, fortalecendo-se para realizar as pretensóes que a metafísica havia em vão estabelecido antes dele. Bergson devia também apresentar, nessas páginas, a metafísica num estado de indistinção tal que fosse possível englobar a metafísica que ele combatia, de modo que ele pudesse mesmo concordar com aqueles que, segundo Kant, contestavam que ela fosse ao menos possível. Em suma, adotar o termo intuição significava aceitar discutir com a metafísica passada e enfrentar os seus desafios, contra aqueles que a criticavam - e Kant era, sem paradoxo, de todos, aquele que havia mais claramente condicionado o sucesso da metafísica à realidade de uma intuição:

Uma das ideias mais importantes e mais profundas da Crítica da Razão Pura é a seguinte: se a metafísica é possível, é através de uma visão, e não de uma dialética [...] Ele definitivamente estabeleceu que, se a metafísica é possível, só pode ser por um esforço de intuição. (BERGSON, 2009, p. 154-155).

"Introdução à metafísica" retoma, desde o seu incipit, a definição que, longe de recusar no quadro de sua dialética transcendental, Kant havia formulado antes que a considerasse inválida para um ser racional e finito. E uma outra prova, se fosse necessária, reside na primeira versão de 1903, em 
que Bergson designava ainda a intuição como "intelectual”, guardando com o epíteto anexado a clara marca de sua proveniência kantiana. $\mathrm{O}$ artigo é, pois, atravessado por uma profunda equivocidade, uma vez que ele retém o sentido de intuição sancionado por Kant, para aquém do qual os Antigos recaíam e para além do qual apenas ele, mediante remodelação, promete avançar.

De fato, há efetivamente duas maneiras de compreender o termo, como também de compreender a experiência integral. E é preciso começar pela maneira antiga. Segundo esta, a intuição podia atingir a essência da coisa, fora de seu desdobramento sensível; a experiência "[...] seria dada de um só golpe em sua integralidade” (BERGSON, 2009, p. 179), enquanto a análise, separada da essência, só poderia dela recolher fragmentos dispersos e espalhados no espaço e no tempo. Assim encarada, a metafísica pretende possuir absolutamente na eternidade aquilo que a ciência, circulando já no relativo, somente estuda ao desdobrar na exterioridade. Num tal dispositivo, a intuição joga seguramente contra a análise; e ela não pode senão aí se perder. A esse respeito, Russel ou Schlick bem que tentaram realizar contra Bergson a análise desconsiderada; eles se enganavam de adversário, e adotavam um conceito de análise que náo passava da contrapartida da intuição tomada em sua antiga acepção. A filosofia analítica se contentava em inverter as prioridades e opunha à experiência integral uma experiência limitada ao conjunto de objetos fixos, distintos e claramente identificáveis. ${ }^{7}$

Além disso, Kant teve razão em desqualificar uma tal intuição derivada de um arquétipo divino, porque a metafísica a que aspirava se elevava alto demais; ela partia em busca imediata do eterno e retornava com um conceito vazio e formal, para o qual dizia haver ali lugar. Ela era, assim, falsamente intuitiva e realmente intelectual: "[...] uma intuição que pretende se transportar de uma só vez no eterno se mantém no intelectual." (BERGSON, 2009, p. 25). Em outros termos, a metafísica pôde, por vezes, apelar à intuição suprassensível, mas, na impossibilidade de alcançá-la, demandava "[...] essa intuição à análise, que é a sua própria negação.” (BERGSON, 2009, p. 193). Tratava-se da alma? É provavelmente por que a intuição verdadeira do eu, frágil e fugaz, não se assemelha em nada à esperada, que ela sempre foi preterida pelos conceitos os quais parecem bem mais sólidos, isto é, no fundo, mais próximos da intuição, tal qual era imaginada. $O$ ponto de vista sobre a coisa se tornava a coisa mesma

\footnotetext{
${ }^{7}$ É o que nos ensina F. Fruteau de Laclos, nas notas da edição crítica (BERGSON, 2009, p. 432 e seguintes), sublinhando a importância que teve o artigo de 1903 para a corrente analítica em vias de se constituir.
} 
e, por um estranho destino, a Ideia platônica, o protótipo do intuitivo. Tal é a ideia eterna de Sócrates que Plotino torna acessível ao voũ e que sua alma, levada pelo devir, não cessa de converter em reflexos sensíveis. Por conseguinte, "[...] é de uma confusão entre o papel da análise e o da intuição que vão nascer as discussóes entre as escolas e os conflitos entre os sistemas." (BERGSON, 2009, p. 190). Ao recusar-se essa intuição, é preciso louvar Kant por ter reduzido a metafísica àquilo que ela era verdadeiramente, a saber, uma simples combinação de conceitos, um “jogo de ideias” (BERGSON, 2009, p. 188) que deveria dividir os filósofos para sempre.

Mas Kant, por sua vez, ainda concedia muito à antiga metafísica; ele construía seu sistema de fenômenos em torno da intuição faltante, secretamente pressuposta, e devia transbordar a concepção negativa do númeno, que desejava desenvolver. Com efeito, ainda que a "coisa em si" não seja a essência dos Antigos, ela ocupa o lugar do Ausente e partilha com ele ao menos a obrigaçáo de ser uma unidade real, o que mostra bem a necessidade, para a análise, de girar em torno da coisa. Recusando-se a entrar na coisa, Kant podia declará-la incognoscível, no entanto, supunha ainda que ela fosse una, uma vez que os dados da sensibilidade explodem de imediato num diverso fenomenal, que, não sendo unido na e pela coisa mesma, devia receber do sujeito transcendental a síntese que lhe faltava. Um curso proferido no Liceu Henry IV, em 18931894, sobre a Crítica da Razáo Pura, o confirma amplamente:

Kant não faz uma ideia simplesmente negativa da coisa em si. Ele se a representa como uma unidade, mas como uma unidade diferente da de nosso pensamento, unidade que não é simplesmente formal, unidade que consiste na presença e na preexistência do todo a suas partes, unidade comparável à da vida, e cuja imagem a natureza nos fornece naquilo que se denomina finalidade. Sem essa hipótese, parece-nos, não há nenhuma razão especulativa para crer numa coisa em si, e para não erigir em absoluto os dados da intuição sensível. (BERGSON, 1995, p. 172).

Em outros termos, supondo que me fosse possível atingir minha alma tal como ela é "em si", eu apreenderia, no mesmo golpe, a unidade viva de minha personalidade, de onde procede a multiplicidade de suas manifestaçôes fenomenais. Um tal ato livre e intemporal é, entretanto, incapaz de ser apreendido intuitivamente e deverá constituir, em Kant, o objeto de um postulado da razáo pura. Vê-se o quanto Kant conserva do antigo dispositivo que ele denuncia, próximo em muitos pontos de Plotino, 
como Bergson sugere com frequência. ${ }^{8}$

Isso confirma, como havíamos enfatizado em outro momento, que "Introdução à Metafísica" é uma crítica tácita à ideia de síntese, e não da análise, cuja fonte Bergson procura antes destacar e retomar na intuição. $\mathrm{Na}$ medida em que ela gira em torno da coisa, a inteligência exerce, com efeito, um trabalho de divisão; mas, quando se a amputa da intuição que lhe dá interiormente seu leste, ela muda de natureza. A análise vira uma simples decomposição, que transforma os elementos analisados em fragmentos a recompor, e obriga a anexar-lhes de fora uma unidade artificial que ela não pode senão lhes impor. É isso que ocorreu a Kant, ao interditar-se o acesso à coisa mesma. Tendo sempre já perdido a unidade original, a sensibilidade deveria partir de uma multiplicidade de sensaçóes dadas, "[...] que derivam náo se sabe como das coisas em si, e que se inserem no tempo e no espaço, formas puras da sensibilidade"; e todo o trabalho do entendimento não podia ser, por consequência, senão um trabalho de síntese, o qual consiste em fazer descer a unidade primitiva da apercepção na "diversidade sensível", a fim de a abarcar, de estender "[...] sobre ela a rede de conceitos puros, de esquemas, de princípios que são outras tantas fórmulas" (BERGSON, 1995, p. 167), que expressam a unidade impessoal do "Eu penso". Ele somente podia colocar um caos numa forma, enquadrando-o em "moldes preexistentes" (BERGSON, 2009 , p. 223). Em suma, para Kant, “[...] se nosso conhecimento fosse do uno ao múltiplo”, a metafísica seria possível - ele iria da intuição à análise, mas "[...] ocorre que de fato ele vai sempre do múltiplo ao uno" - e da análise à síntese, pois, com efeito, "[...] da intuição pode-se passar à análise, mas da análise não se passa à intuição.” (BERGSON, 2009, p. 202).

Deve haver, então, uma outra maneira de compreender a intuição, que é a de Bergson, tal que ela permita realizar a metafísica ao mesmo tempo em que proíbe retornar aos Antigos. É que Bergson os reprovou menos por ter ido tão longe do que por ter colocado seu ideal tấo alto, que não puderam atingi-lo, a não ser através de conceitos vazios - Ideias transcendentais. $\mathrm{O}$ único erro de Kant foi, em seguida, ter-se privado da intuição, ao colocar, com seus adversários, o absoluto como um termo separado, sem aperceberse de que o absoluto está, ao contrário, “[...] bem próximo de nós e, numa certa medida, em nós” (BERGSON, 2007, p. 298), e que a intuiçãa, por

${ }^{8}$ Cf. "La perception du changement", (BERGSON, 2009, p. 155); Cours du Collège de France de 1906-1907 sur "Les théories de la volonté", Mélanges, p. 717; "Cours sur Plotin", École normale supérieure, provavelmente 1898-1899, Cours, v. IV, H. Hude (Éd), Paris: PUF, 1995, p. 47. ("Épiméthée"). 
essa razão, não tem nem mesmo necessidade "[...] de se transportar para fora do domínio dos sentidos e da consciência.” (BERGSON, 2009, p. 141). Certamente, foi necessário, para tanto, que ele fizesse a humilde experiência da duração pura, em que a consciência é imediatamente mergulhada e já assegurada de tocar, ali embaixo, um absoluto, pois é por esse contato que Bergson pode reformar o sentido da intuição. Por ele, Kant teria descoberto que a unidade não é exterior ao múltiplo, mas interior a ele, em virtude de uma multiplicidade de fusão ou de interpenetração. A síntese aí é imanente, por assim dizer, dada imediatamente antes que a reflexão a refrate no espaço e a analise numa multiplicidade de instantes separados. É, assim, o fato de aproximar o fenômeno e a coisa em si e religar a análise à intuição, nem que seja por um fio, insuflando-lhes numa e noutra um sentido novo, que permite a Bergson remodelar consideravelmente o que é preciso entender por experiência, uma vez que ela se amplia, a ponto de integrar a coisa mesma. Veja-se, inversamente, como a análise que Bergson faz girar em torno da coisa quase não se move senão no espaço, reservando à duração do ser, contra Kant, o objeto de uma intuição! A experiência integral não é intuição, menos ainda análise, porém, é aquela que, somando suas competências, só conhecerá bem uma coisa mediante tê-la observado de fora e experimentado de dentro.

Ao aceitar a simplificação à qual Bergson se autoriza, em seu curso sobre Kant, já citado aqui, pode-se dizer que "[...] a Analítica transcendental de um lado, a Dialética transcendental de outro, provarão a legitimidade da física, de uma parte, a ilegitimidade da metafísica, de outra" (BERGSON, 1995, p. 155) e que Kant amputou, por isso mesmo, a experiência de sua metade, seja que Bergson aceite com ele dizer que a física é verdadeira sob a condição de não ser real (Matéria e Memória), seja que ele considere que a física só é válida ao recusar estender-se sobre a totalidade do real (A Evolução Criadora). Por conseguinte, o método do cálculo infinitesimal oferece suficientemente bem a ideia que é preciso se fazer da metafísica bergsoniana ${ }^{9}$, porque, ao defini-la como “a experiência integral” (BERGSON, 2009, p. 227), Bergson intenciona transcender a experiência objetiva que Kant havia fundado, na Analítica transcendental, até abrir-se à coisa em si, e integrar o próprio real que a Dialética transcendental havia fechado, em dupla rodada. Não é mais questão, assim, para o espírito, atingir a intuição sem a ajuda da análise, mas sim dilatar aquela através desta, ao operar "diferenciaçôes qualitativas" (BERGSON,

${ }^{9}$ Cf. MILET, J. Bergson et le calcul infinitésimal. Paris : PUF, 1961 ; cf. LAPOUJADE, D. Puissances du temps. Paris: Minuit, 2010, ch. 1. 
2009, p. 215). A intuição da duração é obstruída pela análise, está menos para além do que para aquém dela. Bergson deve criticar os dados que a inteligência lhe apresenta, se ele quer ultrapassar a condição humana e "[...] buscar a experiência em sua fonte”, ali onde ela é propriamente metafísica. Ao reconstituir a forma da curva "[...] com os elementos infinitamente pequenos de que nos apercebemos assim da curva real", a "[...] démarche extrema da pesquisa filosófica é um verdadeiro trabalho de integração." (BERGSON, 2008, p. 205-206).

Assim se explica a atitude de Bergson com respeito a Kant, que foi sempre ambivalente, esboçando as duas vias possíveis entre as quais a Crítica da Razão Pura se dividia a seus olhos. Matéria e Memória estigmatiza tão bem “o idealismo kantiano" (BERGSON, 2008, p. 255; 259), o qual afirmava a relatividade de nosso conhecimento, quanto o "realismo kantiano" (BERGSON, 2008, p. 259-260), o qual declarava a "coisa em si” incognoscível, fazendo oscilar Kant entre duas correntes, sem que este tivesse seguido nenhuma das duas tendências até suas consequências extremas. É preciso, entretanto, esperar o último capítulo de $A$ Evolução Criadora, para que Bergson tematize essa dupla tendência inerente à filosofia de Kant. De um lado, "[...] ela não é, escreve ele, senão um prolongamento da metafísica dos modernos e uma transposição da metafísica antiga." (BERGSON, 2007, p. 355). Nesse ponto, Bergson reinveste a crítica que lhe endereçava em "Introdução à Metafísica": o kantismo não é senão um platonismo em que as Ideias ilegítimas, se forem consideradas como coisas (metafísica), tornam-se legítimas se descem à terra para serem relaçôes (ciência). Desse modo, "[...] toda a Crítica da Razão Pura repousa assim sobre o postulado de que nosso pensamento é incapaz de outra coisa senáo platonizar" (BERGSON, 2009, p. 223, grifos do autor). Aqui como ali, o real acaba por se resolver em termos inteligíveis. Mas, por um outro lado, reduzindo ao mínimo as hipóteses das quais a ciência mecânica tem necessidade, Kant não vai tão longe quanto Espinosa ou Leibniz, e freia sua expansão metafísica, ao se rebelar nitidamente diante da coisa em si. Assim, ele "[...] detém esse dogmatismo sobre o declive que o fazia deslizar muito longe em direção à metafísica grega.” (BERGSON, 2008, p. 356). E é nesse ponto que Bergson distingue uma segunda filosofia em germe, pois o recuo de Kant permite assegurar à física de Galileu uma extensão indefinida, ao apostar em sua demissão metafísica. Ao se reportar apenas aos fenômenos, Kant libera novas terras desconhecidas que a coisa em si abre e fecha, imediatamente, indicando aquilo cuja entrada ela nos impede, na impossibilidade de aí penetrar com uma "intuição intelectual": 
Por ali ele traçava a via para uma nova filosofia, que se teria instalado na matéria extraintelectual do conhecimento por um esforço superior de intuição. Coincidindo com essa matéria, adotando o mesmo ritmo e o mesmo movimento, a consciência não poderia, por dois esforços de direção inversa, elevando-se e abaixando alternadamente, apreender de dentro e não mais de fora as duas formas da realidade, corpo e espírito? (BERGSON, 2008, p. 356).

Em outros termos, o recuo metafísico da física liberava com a coisa em si uma matéria tornada inalienável pela inteligência, mas Kant se interditou de outra maneira o acesso por tê-la elevado muito alto, resignando-se a náo poder alcançá-la. Nesse sentido, ele traçava uma via nova, ou antes, convocava novamente "[...] esse elemento essencial da filosofia de Descartes que tinha sido abandonado pelos cartesianos." (BERGSON, 2007, p. 357). No entanto, em lugar de revivificar as intuiçóes cartesianas, ele preferiu expulsá-las fora de si, na "coisa em si", em vez de aceitar a sua doação imediata, como Descartes havia consentido antes dele: o sentimento da liberdade, a união da alma e do corpo etc. Ele, que poderia ter dado um passo a mais que Descartes, acabou dando um passo a menos. A liberdade estava exilada, elevada à "[...] altura dos númenos" (BERGSON, 2007b, p. 175), e a união entre a sensibilidade e o entendimento tornava-se "[...] uma arte oculta nas profundezas da alma humana” (KANT, 2008, p. 226). Mas, ao menos, ainda que Kant somente tenha podido restabelecer sua verdade sobre o plano moral, na impossibilidade de uma experiência intuitiva verdadeira, já se tratava de coisa distinta de suprimir até mesmo sua possibilidade, negando pura e simplesmente que haja tempo, que haja liberdade, que haja união, como tinham feito os cartesianos e, na liderança desse grupo, Espinosa e Leibniz; tratava-se de delimitar o lugar vazio que a metafísica podia novamente ocupar, para "[...] um cartesianismo revivificado" (BERGSON, 2007, p. 357). Ao partir para a conquista desses novos territórios, Bergson se dá a intuição que Kant se recusava. Ao mergulhar na duração pura, ele explicita o projeto de integrar progressivamente à experiência essas porçóes do real diante das quais Kant permanecia impedido.

\section{A retomada da estrutura tripartite da CRítica}

Que pode efetivamente significar, para Bergson, engolfar-se assim na via que indicava Kant? À medida que reflete sobre a metafísica que desenvolve, Bergson parece querer remanejar a estrutura tripartite da Crítica (Estétical 
Analítica/Dialética) e de tal maneira que ela possa acolher a intuição que Kant havia condenado. Ainda que a fórmula seja táo rápida quanto exagerada, poderíamos sustentar que Bergson é um Kant que teria previamente descoberto a intuição da duração, e que reescreveria a Crítica da Razão Pura sob o golpe de sua descoberta. Longe de construir sua filosofia contra Kant, como se sustentou frequentemente, segundo Barthélémy-Madaule, numa “[...] oposição decidida e decisiva em relação a Kant” (PHILONENKO, 1994), Bergson encontra nele, ao contrário, um potente aliado para melhor penetrar no aprofundamento metafísico da realidade intuitiva, na qual Descartes já tinha começado a engajar-se. As intuiçóes cartesianas, fracas, marginais, e rapidamente recusadas pelos próprios cartesianos, encontrarão, com efeito, na Crítica da Razão Pura, um dos instrumentos de sua intensificaçáo. Kant havia dado um passo atrás, em relação aos avanços de Descartes. Não seja por isso, o kantismo de Bergson dará um passo adiante e será, segundo seus termos, que é preciso tomar ao pé da letra, um "cartesianismo revivificado". Bergson é aquele que realmente quis introduzir "Descartes em Kant", ao verter uma matéria cartesiana numa forma kantiana. Ao propor reimplantar a metafísica moderna, passando-a sob o crivo da Crítica, Bergson deve revisitá-la, investi-la de dentro, consciente de que pode ali vivificar a intuição, em lugar de deixar que ela se apague.

\section{- Estética Transcendental}

É pela Estética que é preciso começar, pois é também por ali que Bergson inicia sua própria leitura da Crítica, no Ensaio sobre os dados imediatos da consciência. A seus olhos, Kant teve o mérito de fazer do tempo e do espaço "[...] intuiçốes e não conceitos" (BERGSON, 1995, p. 153), distinguindo a sensibilidade e o entendimento ali onde eles estavam, antes de sua obra, confundidos. Seu erro foi ter acreditado que era necessário demonstrar sua idealidade transcendental para poder conferir-lhes uma realidade empírica. A intuição formal do espaço pode ela própria ser objeto de uma experiência real, e esta é a razão pela qual, em $A$ Evolução Criadora, Bergson proporá, em lugar da dedução transcendental, uma gênese real da espacialidade e da inteligência, engendrando-se uma à outra. Ele acrescentará à tese kantiana uma "[...] inteligência aprimorada pela intuição" (WORMS, 2001, p. 453), permitindo fundar o conhecimento intelectual na própria realidade, reservando à física 
tocar o absoluto pela metade. Porém, isso não é provavelmente o que se pode chamar de uma crítica a Kant, mas, antes, um reajustamento da doutrina, uma vez atualizada pelo evolucionismo. Bergson pode também afirmar, em consonância com Kant, no Ensaio, que o espaço é uma "[...] forma a priori da sensibilidade" (BERGSON, 2007b, p. 62-63) e continuar a dizer, em $A$ Evolução Criadora: "[...] o que a Estética Transcendental de Kant nos parece ter estabelecido de uma maneira definitiva é que a extensão não é um atributo material comparável aos outros." (BERGSON, 2007, p.205). É que, tendo "[...] admitido que o espaço homogêneo é uma forma de nossa sensibilidade" (BERGSON, 2007b, p. 177), Bergson pode melhor lhe disputar o tempo em favor do qual o real se reencontra, matéria heterogênea e contínua. Tal é o ponto tênue sobre o qual se concentra a crítica de Bergson: Kant perdeu a experiência da duração, por causa do paralelo indevido que estabeleceu entre o tempo e o espaço, confundindo "[...] a verdadeira duração com o seu símbolo" (BERGSON, 2007b, p. 175).

O ponto é tênue - um tempo espacializado - contudo, na perspectiva de um kantismo de Bergson, essa objeção não é o que fecha o diálogo com Kant, mas sim o que o abre. Se Bergson tivesse desejado rejeitar o criticismo inteiramente, ele não teria concentrado seu ataque num ponto tão reduzido quanto a noção de tempo, na Estética Transcendental. Aliás, era realmente uma verdadeira crítica? Bergson reconheceu muito bem que ele não poderia ter começado por extrair a experiência da duração ao espaço que de ordinário lhe é imposto, se Kant não tivesse começado por distinguir matéria e forma do conhecimento. E, como conquistar uma tal distinção, e torná-la "bem nítida", sem antes forçá-la um pouco, sem começar por assimilar o tempo ao espaço, e por fazer do tempo uma forma como o espaço? Sem esse primeiro exagero, escreve efetivamente Bergson, "[...] sem dúvida essa distinção capital jamais teria sido feita.” (BERGSON, 2007b, p.176), enquanto, uma vez efetivada, sempre chega o momento de reduzir o seu alcance. Uma vez realizada, Bergson podia sempre nuançar essa distinção, "muito acentuada", e reintroduzir o tempo na própria matéria de nosso conhecimento.

É que não se trata, para ele, de fazer com que um sistema desabe sobre si, ao retirar-lhe uma pedra, mas, ao contrário, de se infiltrar nele depois de ter cavado uma brecha, de sorte a tornar o kantismo mais maleável, ao nele verter a intuição descoberta. $\mathrm{O}$ sistema kantiano era impermeável ao real: com a experiência da duração, Bergson encontra, como escreve Péguy, "[...] o nó de resistência, e de fraqueza, como o defeito da armadura, quase inicial, 
particularmente bem situado, particularmente bem encontrado, senão de todo o kantismo, ao menos de todo o kantismo crítico." (PÉGUY, 1907, p. 667). E, graças a esse defeito na armadura, o kantismo até então invencível vai conhecer a ferida do real, o qual ele náo pode mais declarar fora de alcance como "coisa em si". Assim, com respeito aos livros posteriores, Bergson não rejeita o kantismo, nem procura demoli-lo, mas encontra nesse ponto da Estética Transcendental o calcanhar de Aquiles desse outro "[...] couraçado do tipo Dreadnought" (BERGSON, 2009, p.124), a falha em que o real, pelo estabelecimento de um único fato - experiência irrecusável - poderá penetrar novamente no sistema e irrigá-lo com sua vitalidade.

O kantismo de Bergson diferencia-se profundamente, nesse ponto, daquele dos sucessores imediatos de Kant, em particular de Schopenhauer, de Fichte e de Schelling. Todos quiseram, com efeito, dominar o Everest kantiano, ao atacá-lo de frente, por seu cume - a Dialética Transcendental. Todos se concediam a intuição intelectual que Kant declarava ultrapassar a condiçăo humana, essencialmente finita, essencialmente sensível. Repetindo o erro dos Antigos, com mais nitidez ainda, eles se despiam do tempo e do espaço para "[...] transportar-se de um salto no eterno" (BERGSON, 2009, p. 26) e recaíam sobre um conceito vazio, a "Vontade", o "Eu" ou, ainda, "o Absoluto" à guisa de intuição. Bergson, ao contrário, se engaja na Crítica da Razão Pura por trilhas desviadas, mais longas, mais penosas, mas, no final, mais seguras de atingir o cume, pois, para tocar a intuição (supra)intelectual, ele só necessita, no ponto de partida, da intuição sensível, convencido de que esta se encontra "[...] em continuidade com aquela por certos intermediários" (BERGSON, 2007, p. 359). O erro dos kantianos consistiu em ter seguido Kant na separaçáo excessivamente franca que ele estabelecia entre ambas, sem se aperceber de que não há outro meio de ultrapassar a experiência humana, senão o de nela penetrar profundamente, de início, ao se instalar na intuição sensível, que já toca o absoluto e promete aprofundar-se em intuição metafísica. E Bergson somente pode passar de uma à outra, através do desvio por uma crítica de nosso instrumento habitual de conhecimento, que ele denomina por vezes com seu nome kantiano "entendimento", e que não pode ser superado, se não conhecermos os seus limites. Entre a Estética e a Dialética, deve intercalar-se a Analítica, a qual precisamos aprender a cavalgar, fortalecidos por conceitos que a inteligência nos oferece e de onde poderá ressurgir, filtrada e intensificada, a frágil luz de nossas intuiçóes evanescentes. 


\section{- Analitica Transcendental}

Bergson também conserva, grosso modo, a Analitica Transcendental no lugar que ela ocupa, ali operando uma série de acomodaçóes, todas destinadas a irrigar os canais do sistema "Crítico" pela experiência intuitiva da duração pura, que é a sua nova fonte e a sua perturbação inicial. Nós reteremos aqui dois rearranjos maiores:

(i) Bergson louvava Kant, dizíamos, por ter sido parcimonioso em relação a Espinosa e Leibniz, uma vez que ele fundava a física de Galileu sobre um mínimo de hipóteses, evitando deslizar muito longe sobre a encosta da metafísica grega. Ao retirar o tempo do número de hipóteses requeridas, Bergson pode ser ainda mais parcimonioso sobre tal caminho, visto que ele funda a validade objetiva da ciência mecânica exclusivamente sobre a espacialidade inerente às coisas. Não há mais necessidade da tábua das categorias, aí compreendida a de causalidade, da qual Schopenhauer não havia ainda se despojado. Não há mais necessidade mesmo de encarar os juízos sintéticos a priori, pois todos estes se exercem num tempo que a ciência procura essencialmente eliminar, embora ignore por vezes que ela tende ao princípio de identidade como a seu fim. Ali " [...] onde a probabilidade é táo alta que equivale à certeza, em aritmética, por exemplo” (BERGSON, 1995, p. 144), Kant teria com efeito podido conceder, ao menos grosseiramente, que as proposiçóes matemáticas podem ser assimiladas a juízos analíticos, em lugar de defini-las como juízos sintéticos a priori. No fundo, o princípio de identidade basta e os quadros da inteligência nele se reabsorvem. Em suma, a noção de espaço sobre a qual se fundam as próprias matemáticas permanece uma base suficientemente sólida para assentar a física de Galileu. E, se Bergson faz dela uma "forma a priori da sensibilidade", depois um "esquema (schème)" (BERGSON, 2008, p. 232, 237, 247), enfim, um esquema $(\text { schéma })^{10}$ do qual dispóe a inteligência, é

\footnotetext{
${ }^{10}$ Nota da tradutora: os termos utilizados em francês são, em geral, igualmente traduzidos por "esquema", contudo, suas conotaçóes diferem aqui, de modo que explicitam uma passagem interna à filosofia de Bergson. O termo schème, largamente empregado em Matéria e Memória, remete a uma incipiente teoria bergsoniana da imaginação. Ele ali indica mais frequentemente uma espécie de esboço ou croqui de caráter dinâmico, referido sobretudo ao corpo e às "tendências motoras", compondo em determinado momento a expressão-chave "esquema motor". O termo pertence também ao vocabulário kantiano, num sentido incorporado pelos dicionários franceses: "[...] em Kant, representaçấo intermediária entre os fenômenos percebidos pelos sentidos e as categorias do entendimento" (verbete "Schème" no Le Petit Robert). Ele poderia ser traduzido por forma ou estrutura, mas, se acrescentássemos que há uma dinamicidade implícita a essa forma. Trata-se antes de esquema “imaginativo”. É importante observar, entretanto, que o termo será referido diversas vezes ao espaço.
} 
porque seu trabalho é deslocá-la da Estética para a Analitica, a fim de fazer valer sobre essa última o peso da constituição da objetividade e restituir à intuiçáo sensível seu acesso imediato às coisas mesmas. Todavia, num outro sentido, um tal rearranjo, que não é senão uma consequência da descoberta da duração pura, conserva o essencial da conquista kantiana, que limita o mecanicismo da ciência e estabelece lugar nítido à metafísica. A distinção kantiana entre a coisa em si e o fenômeno é, com efeito, muito acentuada, para que Bergson a aceite tal e qual, e bem rapidamente substituída pela distinção entre o todo e a parte. Porém, nós repetimos muitas vezes, ela não deixava de fornecer certos benefícios. Sem ela, com efeito, “[...] o princípio de causalidade e, por consequência, o mecanicismo da natureza valem(riam) para toda coisa em geral.” (BERGSON, 2007, p. 135). Sem a existência da coisa em si, “[...] como os princípios do conhecimento sáo unicamente destinados a organizar a experiência e convergem para o mecanicismo, o mecanicismo invadirá (iria) tudo." (BERGSON, 2007, p. 134). Em suma, a física, aos olhos de Kant, não recebe sua validade senão na medida em que perde a coisa em si, o que será dito em Matéria e Memória, ou ao menos abandona metade do real, como A Evolução Criadora retificará. Em outros termos, a verdade das ciências apoia-se sobre um contrato tácito que lhes interdita transbordar sobre as coisas em si mesmas, aplicar os princípios do conhecimento ao que lhes é refratário, produzindo as ilusôes transcendentais da razão pura. Logo, tudo se inverte: não é Bergson que pode ser acusado de pré-crítico, mas sim aquele que foi seu adversário mais feroz: o materialismo. Belo retorno ao remetente! São efetivamente suas teses ou as do monismo contemporâneo que "[...] se encontram, diz ele ainda em seu curso, atrasadas sobre a crítica kantiana." Elas transbordam sobre a dialética transcendental e pretendem recobrir a realidade em si com essa camada conceitual que a Crítica da Razão Pura havia precisamente tido êxito em conter, ao torná-la disponível para uma outra

Já o termo schéma se aproxima das ideias de plano e simplificação, e está relacionado mais diretamente com a teoria da inteligência desenvolvida em $A$ Evolução Criadora. Ali ele é utilizado, também e sobretudo, para a caracterização do espaço. A inteligência é, para Bergson, a faculdade que levará bem mais longe a esquematização do corpo e dela fará uma representação, uma ideia. No movimento central de $A$ Evolução Criadora, em que a inteligência tem suas funçôes determinadas à luz de seu papel na história evolutiva, encontramos, nesse contexto, passagens dedicadas ao espaço, definido como "o esquema (schéma) de nossa açáo possível sobre as coisas.” As traduçóes brasileiras da Editora Martins Fontes escolhem o mesmo termo, esquema, para as duas ocorrências, e respeitamos aqui esse uso. Em suma, os dois termos se traduzem por esquema, mas o peso da intelectualidade recai sobre schéma, enquanto schème está mais diretamente implicado com o corpo e com a imaginação. Agradeço a meu colega Bento Prado Neto, tradutor de várias obras de Bergson, pelo auxílio em relaçáo a esta e outras passagens, neste texto. 
experiência. Acrescentemos que a distinção, repetida por Bergson, entre o mecanicismo como "método", que é preciso louvar, e o mecanicismo como "doutrina” (BERGSON, 2007, p. 346), que é preciso condenar, é ainda a Kant que ele deve. Kant evidenciou, com efeito, na sua dialética, que há certamente um interesse especulativo em supor extensível ao infinito o determinismo dos fenômenos, o de "[...] encorajar e de fazer avançar o saber" (KANT, 2008, p.460), mas sob a condição expressa de não o colocar de maneira tão dogmática quanto o dogmatismo ao qual se opóe.

(ii) A segunda e principal remodelação que Bergson efetua, no seio da Analítica Transcendental, consiste em fundar a unidade do mecanicismo sobre a ação, e não mais unicamente sobre o pensamento, ou seja, sobre a unidade sintética da apercepção - "[...] o eu penso deve necessariamente poder acompanhar todas as minhas representações” (KANT, 2008, p. 198). Tal é a teoria do conhecimento que Bergson esboça, desde Matéria e Memória, e que lhe permite retornar ao instrumento de nosso conhecimento, nele sublinhando sua limitação, e não mais sua relatividade, pois, por esse teor pragmático que lhe confere, Bergson saberá como ultrapassar a inteligência em direção a uma metafísica positiva, o a priori revelando-se ser apenas hábito. Mas novamente o essencial do que Kant conquistou é conservado. Os limites, para serem superados, devem permanecer tais como, antes de Bergson, Kant havia fixado, na Analitica Transcendental. Que eles sejam princípios do conhecimento ou quadros para nossa ação não muda nada no caso: ao abandonar o terreno da experiência para um uso puramente especulativo de si mesmos, eles conduzem igualmente a criar "dificuldades insolúveis" que se devem à "[...] contradição em que a inteligência pode colocar-se consigo mesma quando especula sobre o conjunto das coisas." (BERGSON, 2009, p. 35). O prefácio à sétima edição de Matéria e Memória conclui sobre uma nota kantiana: "[...] os hábitos contraídos na ação, remontando à esfera da especulação, criam aí problemas factícios e [...] a metafísica deve começar por dissipar essas obscuridades artificiais.” (BERGSON, 2008, p. 9). É assim o mesmo gesto de transgressão que Bergson denuncia e que Kant denunciava: a inteligência engendra antinomias tão logo abandona o solo da experiência à qual ela é praticamente destinada - a da matéria.

Essas duas remodelaçóes têm como efeito reconciliar ciência e metafísica ali onde Kant consagrava sua compartimentação, uma vez que, ao cruzar suas esferas, é a duplo título que Bergson recoloca a experiência no lugar de honra, ao reconduzir primeiramente a metafísica ao campo estreito 
dos fatos (Analítica) e, em seguida, ao conferir à experiência, graças à intuição, uma extensão que ela não tinha em Kant, invadindo o próprio campo da metafísica (Dialética). Em outros termos, de um lado, Bergson transporta os problemas metafísicos para o terreno da observaçáo, a fim de que eles parem "[...] de alimentar indefinidamente as disputas entres as escolas no campo fechado da dialética pura." (BERGSON, 2008, p. 9). E, de outro lado, uma vez que ele já mostrou, no Ensaio sobre os dados imediatos da consciência, que uma experiência intuitiva transborda os quadros práticos que a formatam, a metafísica não será mais declarada ser o que engendra as antinomias, mas, ao contrário, o que as resolve. Acompanhada dessa dupla exigência, a dialética transcendental, que traçava as arestas de uma metafísica impossível, poderá progressivamente em Bergson se transformar em metafísica concreta, de sorte que, partindo “[...] das premissas colocadas por Kant", Bergson pode afirmar, num de seus cursos ainda inédito, que ele pode tirar de tais premissas "[...] uma outra conclusão, absolutamente diferente" ${ }^{11}$ e, por uma feliz inversão, revivificar a metafísica no lugar preciso em que Kant a havia deixado morrer.

\section{- Dialética transcendental}

Tal é, para concluir, a Dialética transcendental que Bergson retoma inteiramente, a qual ele conserva mesmo rigorosamente como crítica sempre válida da metafísica. É preciso precaver-se contra uma leitura rápida e evitar dizer que ela é uma das aquisiçôes sobre a qual Bergson, ao contrário, não retornará: a Crítica de Kant "[...] é, em nossa opinião, definitiva no que ela nega.” (BERGSON, 2007, p. 206). Armada de seus princípios físicos, a razão estava segura de a tomar como inimigo e transformar a metafísica num campo de batalha. Logo, é imensa a vantagem de tê-la proibido de pronunciar-se pró ou contra a existência da alma, do mundo ou de Deus, invalidando os argumentos especiosos que ela se opunha a si mesma. E Bergson pode lhe ser grato por tê-lo livrado da antiga metafísica, que procedia por combinação de conceitos, tal como ela atuou de Platâo a Leibniz e para além, e que era a única metafísica que Kant conhecia. Por essa razão, Bergson emprega o termo "dialética", em lugar de "dialética pura", em um sentido de bom grado kantiano, mas surpreendentemente aproximado de seu sentido platônico (BERGSON, 2009, 87-88, 98). Kant preservava, assim, todo um domínio

${ }^{11}$ Conforme Cours au Collège de France sur "L'Idée de temps", séance du 11 avril 1902, Dactylogramme $n^{\circ} 1, p .9$, Bibliothèque du Fonds Doucet, à qual agradecemos a autorização para reproduzir o excerto. 
de onde ele tinha reprimido a inteligência, sob pena de que ela ainda o devastasse. Mas ali onde ele evitava engajar-se, "instalar-se", "por um esforço superior de intuição", retirando-se por sua vez como uma onda depois de seu refluxo, Bergson decide ir, com a intuição reconciliadora. É, com efeito, fortalecido pela intuição que ele pode inverter o sentido da Crítica kantiana: tão logo a experiência se autoriza, de fato, a transgredir a proibição kantiana, a inteligência deixa de ser "relativa" e se revela "limitada" (BERGSON, 2007, p. 357) aos quadros práticos nos quais ela encerrava a experiência. Tão logo o limite ultrapassado, e a experiência descoberta para além de suas fronteiras, evidencia-se que a metafísica não transgride a experiência, porém, que ela deve, ao contrário, transgredir o entendimento, se ela quer se definir como "experiência integral". A antiga metafísica jogava com conceitos vazios, numa dialética infinita que colocava a inteligência às voltas consigo mesma; a nova se apoia sobre uma intuição que lhe permite transbordar a inteligência em direção a uma experiência propriamente metafísica, mais larga que as condições de possibilidade que a colocavam em cena e a submetiam à objetividade. É que não há recobrimento perfeito da inteligência sobre a experiência, mas, quando, por uma opinião autoritária, Kant afirmou a segunda mais estreita que a primeira, Bergson a descobre mais larga, pois basta que a intuição tenha êxito, como em Bergson, em penetrar na coisa mesma, para que ela escape à visada do conceito, transbordando-a por todos os lados. Autorizando-nos um plágio por antecipação, poderíamos dizer que o fenômeno é para ele saturado de intuição, a ponto de ultrapassar todo conceito e subverter até os princípios do conhecimento. ${ }^{12} \mathrm{E}$, uma vez que a metafísica bergsoniana é, como dizia Bergson, "[...] totalmente saturada de experiência" (BERGSON, 1972, p. 501), transcender a física significa "[...] transcender a inteligência pura" (BERGSON, 2007, p. 201), juntar-se à experiência nua e não a abandonar.

Explicitar o kantismo de Bergson, como o fizemos, nos coloca em posição de conferir um estatuto preciso à metafísica bergsoniana, sendo por isso mesmo ocasião de devolver seu sentido pleno a uma passagem que nos parecia ainda obscura na Introdução ao livro O Pensamento e o Movente. Bergson ali declara que a ciência abarca uma parte da realidade e, então, "[...] já preenche uma metade do programa da antiga metafísica” (BERGSON, 2009, p.43), e que a metade restante deve retornar à carga da metafísica propriamente dita. A distinção wolffiana entre metaphysica generalis e metaphysica specialis é efetivamente aqui retomada, mas na exata medida em que ela recobre os contornos

${ }^{12}$ Cf. MARION, J.-L. Étant donné. Paris: PUF, 1997 (“Épiméthée”), $\$ 21$ - “Esquisse du phénomène sature”, p. 280. 
que lhe dava a Crítica da Razão Pura. A ciência física fundada sobre a analítica transcendental toca o absoluto e podia reencontrar com Bergson seu antigo nome de metafísica geral, "[...] se ela não preferisse guardar o nome de ciência.” (BERGSON, 2009, p. 43), porque, depois que Kant substituiu “[...] o orgulhoso nome de uma ontologia" por aquele "[...] modesto de uma simples analítica do entendimento puro" (KANT, 2008, p. 300), Bergson acaba por lhe conceder tocar uma das duas partes do absoluto, e à própria ciência realizar uma das metades do programa da metafísica antiga, isto é, a metaphysica generalis: o conhecimento da matéria. Por outro lado, a metafísica invalidada pela dialética transcendental deve poder referir-se à outra metade do absoluto: o conhecimento do espírito. Seguindo Deleuze e Alain de Lattre, todos aqueles que quiserem ver uma ontologia bergsoniana terão que haver-se, entre outras coisas, com essa declaração bergsoniana que, em nossa opinião, enterra definitivamente sua própria possibilidade. Deleuze elaborou uma "ontologia da duração" pela qual Bergson teria procurado, ao criar seus próprios problemas, liberar-se dos antigos que se havia acreditado serem eternos, os da alma, do mundo e de Deus. É preciso, entretanto, reconhecer que é o contrário que é totalmente verdadeiro. Não somente não há e não pode haver ontologia em Bergson - teoria do conhecimento obriga - mas, se há metafísica, ela não será senão a metaphysica specialis da qual Deleuze quis desembaraçar-se e que se coloca sobre a alma, o mundo e Deus (ele que faça bom proveito). Acrescentemos, enfim, que, se ele segue a Crítica da Razão Pura, Bergson pode nomear diferentemente a tripartição que a governa, recobrindo em certo sentido a outra tripartição que Frédéric Worms soube discernir em sua obra, notadamente em Matéria e Memória ${ }^{13}$ : psicologia, teoria do conhecimento e metafísica - com a diferença de que será necessário compreender aqui por psicologia a realidade tal e qual é dada à consciência imediata, e não a disciplina que a toma por tema de seu estudo.

Kant terá sido menos o Cristóvão Colombo de um novo mundo que o seu Moisés, morrendo antes de nele entrar e se detendo diante de suas fronteiras, já muito velho para crer que poderia atravessá-las, porém, apontando o dedo em direção a essa terra incógnita, lançando como que um apelo às novas geraçóes, as quais sentirão a coragem de se aventurar e viver experiências ainda virgens. Bastou a Bergson descobrir a duraçáo pura na profundidade de uma intuição para inverter o sentido da Crítica kantiana: o campo da metafísica especial que a dialética transcendental tinha barrado se libera novamente, mas

${ }^{13}$ Conforme. WORMS, F. Introduction a Matière et mémoire. 2. ed. Paris : PUF, 1997/2008 ("Les Grands Livres de la philosophie”). 
não sem ter se beneficiado da iluminação efetuada pelo trabalho crítico. Com efeito, se Kant permitiu definitivamente rejeitar a metafisica dogmática, há fortes chances de que a retomada intuitiva que Bergson opera não faça recair a nova metafísica nos defeitos da antiga, de sorte a não se identificar com nenhuma das posiçóes já ocupadas e previamente condenadas por Kant, no quadro de sua dialética pura. É preciso, então, ir mais longe, e uma outra contribuição é necessária, se quisermos mostrar como a obra de Bergson segue passo a passo o programa de uma metafísica especial, repassando por onde Kant havia passado, no passo que era o seu, no ritmo das ideias transcendentais da razão pura e na ordem exata que ele lhes havia conferido, na Dialética transcendental. Se, aliás, essa interpretação se asseverasse justa, estaríamos igualmente em posição de discernir, graças às respectivas leituras de Kant, os interesses muito divergentes que motivam, em Heidegger e em Bergson, sua vontade de introduzir novamente a metafísica: uma releitura ontológica da Analitica transcendental no Kantbuch ${ }^{14}$ e uma releitura empírica da Dialética transcendental, na obra de Bergson. Kant havia, com efeito, apresentado ali um magnífico programa cujas promessas - declaradas insustentáveis - Bergson, com a intuição em proa, quis sustentar. Contentemo-nos aqui em desenhar o seu quadro, na esperança de a ele retornar em detalhe, num outro lugar:

\section{ENSAIO SOBRE OS DADOS IMEDIATOS DA CONSCIÊNCIA}

I) Psicologia racional: os paralogismos da razão pura

1) Paralogismo da substância

2) Paralogismo da simplicidade

3) Paralogismo da personalidade

Esses três conceitos resumem, aos olhos de Kant, a "espiritualidade" (KANT, 2008, p. 400).

\section{Matéria E MEMORIA}

4) Paralogismo da idealidade (da relação exterior)

Seu estatuto difere dos três primeiros paralogismos, pelo fato de que ele

\footnotetext{
${ }^{14}$ Ver HEIDEGGER, Kant et le problème de la métaphysique. Trad. A. De Waelhens et W. Biemel. Paris: Gallimard, TEL, 1953/1981.
} 
relaciona a alma "aos objetos no espaço" e se coloca sobre "o comércio com o corpo".

II) Cosmologia racional: as antinomias da razão pura

1) Primeira antinomia da razão pura

2) Segunda antinomia da razão pura

\title{
A eVOluÇáo CRiadora
}

3) Terceira antinomia da razão pura

4) Quarta antinomia da razão pura

\section{As DUAS FONTES DA MORAL E DA RELIGIÁO \\ III) Teologia racional: o Ideal da razão pura}

RIQUIER, Camille. The intuitive overcoming of metaphysics: Bergson's Kantianism. Trans/form/ação, Marília, v. 40, n. 2, p. 217-242, Abr./Jun., 2017.

\begin{abstract}
Aвstract: This paper examines important aspects of Bergson's complex relationship with Kant. Our hypothesis defends that Bergson can not be considered a mere opponent of Kant, but that instead his philosophical project aims to renew metaphysics, taking into account the limits that the Kantian critique has imposed. In this sense, the Critique of Pure Reason, to which Bergson devoted his attention, serves as a guide and support for reworking metaphysical questions that the philosophy of duration seeks to answer. We have also shown that if Bergson criticized Kant at various points in his work, it was only to the extent that the Critique was an impediment to moving forward. The relation between Kantian interdictions to speculative reason and the illusions of intelligence dissolved by the analysis of Creative Evolution shows how Kant condenses illusions that existed before him. In in this sense, Bergson is neither pre-critical nor post-Kantian. To sum up, we argue that Bergson displaces critical analysis and breaks with Kant from the inside of Kant's philosophy, which Bergson divides into two tendencies, one that he rejects as old, another that he accepts.
\end{abstract}

KEYwords: Bergson. Kant. Metaphysics. Creative evolution. Reason. Intelligence.

\section{REFERÊNCIAS}

BERGSON. H. L'Évolution créatrice. Paris: PUF, 2007 (Quadrige). 
. Essai sur les données immédiates de la conscience. Paris: PUF, 2007b (Quadrige). . Matière et mémoire. Paris: PUF, 2008. (Quadrige).

. La Pensée et le mouvant. Paris: PUF, 2009. (Quadrige).

. La conscience et la vie. In : . L'Énergie spirituelle. Paris: PUF, 2009b (Quadrige).

. Leçons sur la critique de la raison pure, Lycée Henri-IV, 1893-1894. In: HUDE, H. (Éd.). Cours, v. III. Paris: PUF, 1995. (Épiméthée).

. Bergson, Le parallélisme psycho-physique et la métaphysique positive, suivi d'une discussion. In : . Mélanges, Paris: PUF, 1972.

BARTHÉLÉMY-MADAULE, M. Bergson adversaire de Kant. Paris: PUF, 1966.

HEIDEGGER, M. Kant et le problème de la métaphysique. Tradução de A. De Waelhens et W. Biemel. Paris: Gallimard, 1953/1981.

KANT, I. Critique de la raison pure. Tradução de A. Renaut. 3. ed. revue et corrigée. Paris: Flammarion, 2008.

LAPOUJADE, D. Puissances du temps. Paris: Minuit, 2010.

MARION, J.-L. Étant donné. Paris : PUF, 1997. (Épiméthée).

MILET, J. Bergson et le calcul infinitésimal. Paris: PUF, 1961.

PANERO, A. Kant, précurseur manqué de Bergson. Revue Philosophique de la France et de l'Etrange: Bergson, Paris : PUF, n. Spécial, 2008.

PÉGUY, C. Heureux les systématiques, posthume. In: CEuvres en proses complètes. Paris: Gallimard, 1905. p. 223-311. (Bibliothèque de la Pléiade).

. Avertissement au Bar-Cochebas de Jérôme et Jean Tharaud. In: Euvres en proses complètes. Paris: Gallimard, 1907. ("Bibliothèque de la Pléiade”).

PERTILLE, J.Aufhebung, meta-categoria da lógica hegeliana. Revista Eletrônica Estudos Hegelianos, ano 8, n. 15, p. 58-66, dez. 2011.

PHILONENKO, A. Bergson ou de la philosophie comme science rigoureuse. Paris: Cerf, 1994 (4ème de couverture).

WORMS, F. L'intelligence gagnée par l'intuition ? La relation entre Bergson et Kant. Les Études Philosophiques, n. 59, p. 453-463, 2001.

. Introduction à matière et mémoire. 2. éd. Paris: PUF, 2008. (Les Grands Livres de la Philosophie). 
; RIQUIER, C. Lire Bergson. Paris: PUF, 2011.

Recebido em 13/12/2016

Aceito em 10/01/2017 
RIQUIER, C. 